\title{
Correlation between anti-dsDNA, complement components C3, C4 and Systemeic Lupus Erythematosus disease activity index
}

\author{
Therese Mary Dhason ${ }^{* 1}$, Euphrasia Latha Jayaraj ${ }^{1}$, Rajeswari Sankaralingam¹, Saranya \\ Chelladurai ${ }^{1}$, Sowndhariya Annamalai ${ }^{1}$, Ramesh Ramamoorthy ${ }^{1}$ \\ ${ }^{1}$ Institute of Rheumatology, Rajiv Gandhi Government General Hospital, \\ Madras Medical College, Tamil Nadu, India.
}

\begin{abstract}
Background: To find out the correlation between anti-ds DNA, complement components C3, C34 and disease activity in SLE. Material and Methods: This cross-sectional study was undertaken over a period of 6 months from January 2016 to June 2016 at a Tertiary Care Centre in South India. Blood samples were collected from 100 patients with active lupus, 100 patients with inactive disease and 100 healthy controls. Serum samples from all the 300 samples were tested for anti- dsDNA by ELISA and C3, C4 by Radial Immunodiffusion. Results: High titre anti-dsDNA was detected in 48 out of the 100 patients with active disease. Mean SLE disease activity index (SLEDAI) of patients with high titre anti-dsDNA was $23.08337 \pm 3.80276(\mathrm{P}<0.001)$ Mean SLEDAI of patients with very low C3 and C4 was $21.4314 \pm 4.88776(\mathrm{P}<0.001)$ and $21.1250 \pm 4.82882(\mathrm{P}<0.001)$. Conclusion: Anti-dsDNA, C3, C4 levels can be adopted as markers of disease activity in SLE. Anti-dsDNA by ELISA is a simple and cost effective method. Radial immunodiffusion can be done for C3 and C4 assay where nephelometer is not available as the procedure is simple.
\end{abstract}

Key words: Systemic Lupus Erythematosus, anti-ds DNA antibody, ELISA, C3, C4, radial immuno diffusion.

This study was presented as a poster at Indian Rheumatology Association Conference 2016, Kochi, Kerala, India.

\section{Introduction}

Systemic Lupus Erythematosus (SLE) is a chronic systemic autoimmune disease and it primarily affects women, with a female to male ratio 6-10:1 and a peak incidence during reproductive age (1).The hallmark of SLE is the wide array of serologic abnormalities, including a polyclonal hypergammaglobulinemia, the presence of antinuclear antibodies (ANAs) and various organ-specific and non-organ specific autoantibodies, circulating immune complexes, and serum complement changes. The presence of some of these serologic abnormalities is important in corroborating the diagnosis of SLE, whereas others are useful in monitoring disease activity (2).
Anti-dsDNA antibodies were the first autoantibodies described in patients with SLE. Anti-dsDNA antibodies can be found in up to $70 \%$ to $80 \%$ of patients with SLE at some time during the course of the disease, these antibodies are very rarely found in patients with other autoimmune conditions and in healthy controls. Furthermore, in many cases there is a relationship between disease activity and the titer of anti-dsDNA. In a larger study, Swaak showed that rise in levels of anti-dsDNA antibodies preceded renal flares in SLE (3) and subsequent independent studies also showed that rises in anti-ds DNA antibody level were associated with flares of activity, either in the kidney or in other organ.
*Corresponding Author: Therese Mary Dhason, Senior Assistant Professor of Microbiology (Immunology) Institute of Rheumatology Rajiv Gandhi Govt. General Hospital Madras Medical College E.V.R.Periyar Road, Chennai-600003, TamilNadu India. E-mail: tmary1964@gmail.com Received: Feb 01, 2017. Accepted: Jul 07, 2017
This is an Open Access article distributed under the terms of the Creative Commons Attribution Non-Commercial License (http://creativecommons.org/licenses/bync/4.0/) which permits unrestricted non-commercial use, distribution, and reproduction in any medium, provided the original work is properly cited.

Journal of Immunology and Clinical Microbiology (C) 2017 
One of the main disease activity indices in SLE-the systemic Lupus Erythematosus Disease Activity Index (SLEDAI) includes raised anti-dsDNA antibodies as a scorable element of disease activity (4).

The initial screen for anti-dsDNA antibodies usually involves testing for the presence of an antinuclear antibody (ANA), either by Immunofluorescence (IF) or ELISA. Anti-dsDNA antibody titer is most commonly measured by ELISA. New forms of ELISA in which the antigen substrate consists of dsDNA coupled with nucleosome increases the sensitivity and specificity of anti-dsDNA. The anti-dsDNA is not just significant for the prognosis of SLE, but also for monitoring disease activity $(5,6)$.

The invitro activation of the complement system by immune complexes of anti-DNA and other autoantibodies is central to the pathogenesis of the glomerular injury and, possibly, to other tissue damage in patients with SLE. Acute exacerbations of the disease can be associated with low serum complement levels. In a comparison of baseline, preflare and at flare values in lupus nephritis, the serum levels of neither $\mathrm{C} 3$ nor $\mathrm{C} 4$ decreased during preflare, but both decreased significantly at flare when compared with baseline values. The sensitivity of $\mathrm{C} 3$ was $75 \%$ but $\mathrm{C} 4$ had a sensitivity of only $41 \%$. Both had a specificity of $71 \%$. Despite its limitations, measurement of native $\mathrm{C} 3$ and $\mathrm{C} 4$ levels has not been replaced by that of cell bound or split products of complement in current practice (7).

Serum complement assay can be either a functional assay in which $\mathrm{CH} 50$ is measured as haemolytic units or components assay like C3,C4 assay. The methods available for C3, C4 assay are nephelometry, radial immunodiffusion and ELISA. Radial Immunodiffusion method is a simple, less skillful method which can be adopted where nephelometer is not available. Determination of the serum titer of anti-ds DNA and of serum complement are the most common and probably the most useful serologic tests that are readily available to the clinicians (8).

This study was undertaken to find out the correlation between anti-dsDNA antibody titer, C3, C4 levels and SLEDAI in patients with active Lupus. The study also included active lupus, inactive lupus and healthy controls to find out the relationship between anti-ds DNA antibody, C3, C4 and the study group.

\section{Material and methods Subjects}

This cross-sectional study was undertaken in Institute of Rheumatology, Rajiv Gandhi Govt. General Hospital and Madras Medical College over a period of six months from
January 2016 to June 2016. Study population included females and males of age group $10-50$ years.

A total of 300 peripheral blood samples were collected from 100 patients with clinically active SLE, 100 with clinically inactive or quiescent state and from 100 healthy controls. Inclusion criteriafor active disease were seizures, psychosis, visual disturbance, headache, arthritis, vasculitis, myositis organic brain syndrome, cranial nerve disorder, new rash, alopecia, mucosal ulcers, pleurisy and pericarditis. Laboratory criteria for active diseases are proteinuria, urinary casts, haematuria, pyuria and low complement. Exclusion criteria: Lupus patients without the above symptoms and laboratory findings. The inclusion criterion is based on SLE disease activity index (SLEDAI). Inclusion criteria for inactive disease is SLEDAI of 4 or less than 4.

\section{Anti- dsDNA ELISA}

The Anti-dsDNA-NCX ELISA (IgG) kits were procured from (Euroimmun, Germany). The antigen substrate consists of dsDNA coupled with nucleosome to the solid phase (9). Highest SLE specificity is ensured through use of a highly-purified nucleosome fraction, which is free of H1, SCL-70 and other non-histone proteins (10). Quantitative analysis of anti- ds-DNA was done as per the kit protocol using the calibrators ( $\mathrm{C} 1$ to $\mathrm{C} 3$ ), the positive control, negative control and the patient samples. The antibody concentration of calibrators was $800 \mathrm{IU} / \mathrm{ml}, 100$ $\mathrm{IU} / \mathrm{ml}$ and $10 \mathrm{IU} / \mathrm{ml}$ for $\mathrm{C} 1, \mathrm{C} 2$ and $\mathrm{C} 3$ respectively.

\section{Principle of the test}

The ELISA test kit provides a semi quantitative or quantitative in vitro assay for human autoantibodies of the IgG class against double stranded, genomic dsDNA in serum. The microtitre plate wells are coated with dsDNA. In the first reaction step, diluted patient samples are incubated in the wells. In the case of positive samples specific $\operatorname{IgG}$ antibodies (also $\operatorname{IgA}$ and $\operatorname{IgM}$ ) will bind to the antigens. To detect the bound antibodies, a second incubation is carried out using an enzyme-labeled antihuman IgG catalyzing a colour reaction. Substrate is added in the next step and the enzyme hydrolyse the substrate producing blue color. On addition of stop solution yellow colour is produced.

\section{Procedure}

It is an indirect ELISA in which the diluted samples, calibrators, positive control and negative controls are added to wells coated with dsDNA. After washing 
enzyme-labelled conjugate was added and incubated for $30 \mathrm{~min}$. After 3 wash, substrate was added and incubated for 15 min. Finally stop solution was added.

\section{Measurement}

Photometric measurement of the colour intensity was done at a wave length of $450 \mathrm{~nm}$ and a reference wavelength of $620 \mathrm{~nm}$ within $30 \mathrm{~min}$ of adding the stop solution. Quantitative assay was performed using calibrators 1, 2 and 3 of antibody concentration $800 \mathrm{IU} / \mathrm{ml}, 100 \mathrm{IU} / \mathrm{ml}$ and $10 \mathrm{IU} / \mathrm{ml}$ respectively.

\section{Interpretations}

The upper limit of the normal range is $100 \mathrm{IU} / \mathrm{ml}$ and samples with $<100 \mathrm{IU} / \mathrm{ml}$ were reported as negative and $\geq$ $100 \mathrm{IU} / \mathrm{ml}$ were reported as positive. The standard curve was obtained by point-to-point plotting of the extinction values measured for the 3 calibrator sera on ' $\mathrm{Y}$ ' axis against the corresponding units on ' $\mathrm{X}$ ' axis. The antibody concentration of serum samples was derived by interpolating the standard curve.

\section{C3, C4 Assay}

The kit used for C3, C4 assay was Radial Immunodiffusion (RID) plates, Diffu-plate procured from (Biocientifica S.A, Argentina).

\section{Presentation of kit}

RID plate for 12 tests contain monospecific serum directed against C3, C4 in an agarose gel layer. Kits were stored in a flat surface at $2^{\circ}-8^{\circ} \mathrm{C}$, tightly closed and upside down to prevent condensation accumulating in the wells.

\section{Principle}

The procedure is based on immuno precipitation in agarose between an antigen and its homologous antibody. It is performed by incorporating one of the two immune reactants (usually antibody) uniformly throughout a layer of agarose gels, and then introducing the other reactants (usually antigen) into wells duly punched in the gel. Antigen diffuses radially out of the well into the surrounding gel-antibody mixture, and a visible ring of precipitation forms where the antigen and antibody reacted. The ratio between ring square diameter (i.e, the area of precipitate) and antigen concentration shows a linear ratio.

\section{Procedure}

Anti-C3 and Anti-C4 incorporated Diffue plates were used for the assay.

Sample
Serum was separated from clotted blood samples and processed on the same day. Samples which could not be processed on the same day were stored at $-20^{\circ} \mathrm{C}$.

The plates were opened and kept at room temperature for $5 \mathrm{mts}$ to allow any possible condensation to evaporate. The wells were filled with $5 \mu 1$ of serum samples using Hamilton syringe. A wet cotton was placed in the center of the plate to avoid agarose dehydration and closed tightly. The plates were kept flat at room temperature for 48hrs.

\section{Interpretation}

Interpretation was by Routine determination, using a reference table with the measuring scale procured, measured rings with $0.1 \mathrm{~mm}$ precision. The results were read directly off the reference table.

Normal range

The normal range of $\mathrm{C} 3$ is $80-160 \mathrm{mgm} / \mathrm{dl}$ and $\mathrm{C} 4$ is 20 $40 \mathrm{mgm} / \mathrm{dl}$.

Statistical analysis was done with SPSS software.

\section{Results}

The anti-dsDNA antibody was positive in $83 \%$ of patients with active lupus. High titre anti-dsDNA was detected in $66 \%$ of active lupus. The mean SLEDAI of patients with high titre anti-dsDNA was $23.0833 \pm 3.80276(\mathrm{p}<.001)$. The data are summarized in Table 1-3.

Table 1. Comparison of anti-dsDNA with SLEDAI.

\begin{tabular}{|c|c|c|c|c|c|c|}
\hline \multirow{2}{*}{$\begin{array}{l}\text { Anti- } \\
\text { dsDNA }\end{array}$} & \multirow[b]{2}{*}{$\mathbf{n}$} & \multirow{2}{*}{$\begin{array}{c}\text { Mean } \\
\text { SLEDAI }\end{array}$} & \multirow{2}{*}{$\begin{array}{c}\text { Std. } \\
\text { Deviation }\end{array}$} & \multirow{2}{*}{$\begin{array}{l}\text { Std. } \\
\text { Error }\end{array}$} & \multicolumn{2}{|c|}{$\begin{array}{l}\text { 95\% Confidence } \\
\text { Interval for Mean }\end{array}$} \\
\hline & & & & & $\begin{array}{l}\text { Lower } \\
\text { Bound }\end{array}$ & $\begin{array}{l}\text { Upper } \\
\text { Bound }\end{array}$ \\
\hline Normal & 16 & 8.9375 & 3.71427 & .92857 & 6.9583 & 10.9167 \\
\hline $\begin{array}{l}\text { Low } \\
\text { positive }\end{array}$ & 13 & 10.1538 & 3.60199 & .99901 & 7.9772 & 12.3305 \\
\hline $\begin{array}{l}\text { Medium } \\
\text { positive }\end{array}$ & 23 & 15.4348 & 3.23090 & .67369 & 14.0376 & 16.8319 \\
\hline $\begin{array}{l}\text { High } \\
\text { positive }\end{array}$ & 48 & 23.0833 & 3.80276 & .54888 & 21.9791 & 24.1875 \\
\hline Total & 100 & 17.3800 & 6.91913 & .69191 & 16.0071 & 18.7529 \\
\hline
\end{tabular}

$33 \%$ of patients with inactive lupus were anti-dsDNA positive. Anti-dsDNA titre was high in $26.2 \%$ of patients with inactive lupus. Among the healthy controls $8 \%$ were anti-dsDNA positive. Anti-dsDNA among the study group is depicted in Figure 1. 


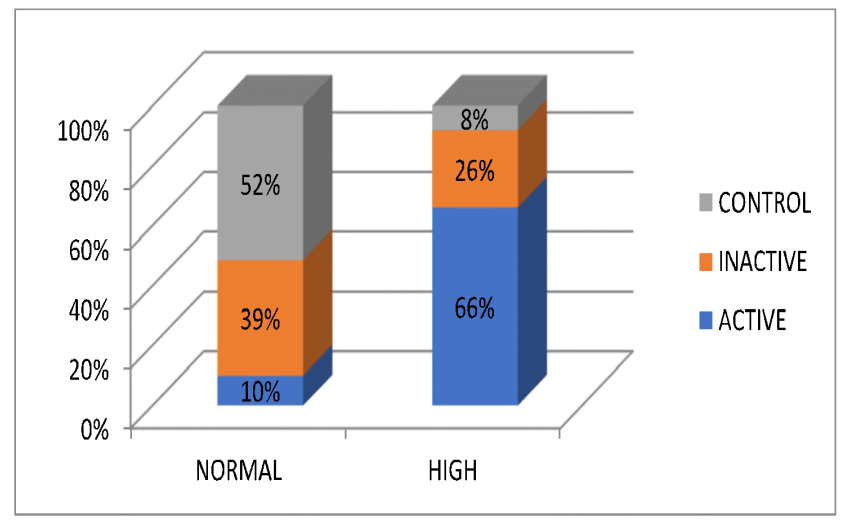

Figure 1. Anti-dsDNA titer in study group.

There was a significant association of high titre antidsDNA and disease activity in the active disease group compared to inactive disease and healthy controls $(\mathrm{p}<0.001)$.

The complement component $\mathrm{C} 3$ assay revealed normal, low, and very low $\mathrm{C} 3$ in $21 \%, 28 \%$ and $51 \%$ respectively in active disease group. There was a positive correlation between very low $\mathrm{C} 3$ and disease activity. The mean SLEDAI of patients with very low C3 was $21.4314 \pm$ $4.88776(\mathrm{p}<0.001)$

Similarly, C4 level in active disease group was normal, low, very low in $15 \%, 21 \%$ and $64 \%$ respectively in active disease group. Positive correlation was found between very low $\mathrm{C} 4$ and disease activity. Mean SLEDAI of patients with very low C4 was 21.1240 ( $\mathrm{p}<0.001$ )

In a large prospective study, the combination of an elevated titer of anti-dsDNA and low serum C3 has a high positive predictive value for the diagnosis of SLE. Serological tests are widely used for assessing disease activity and predicting exacerbations. Determinations of the serum titer of anti-dsDNA and of serum complement are the most common and probably the most useful serological tests that are readily available for the clinician. $\mathrm{C} 3$ and C4 levels had a negative correlation with antidsDNA and is depicted in Figure 2 and 3.
Figure 2. Anti-dsDNA vs C3 in study group.

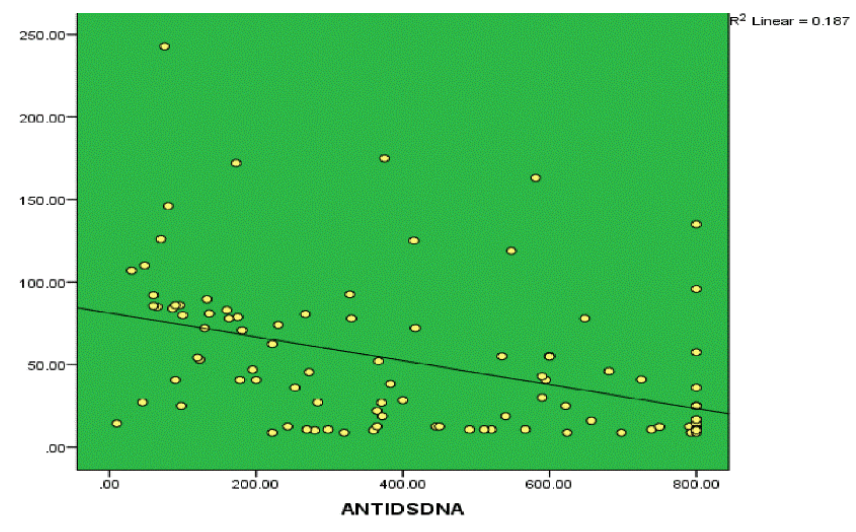

Figure 3. Anti-dsDNA vs C4 in study group.

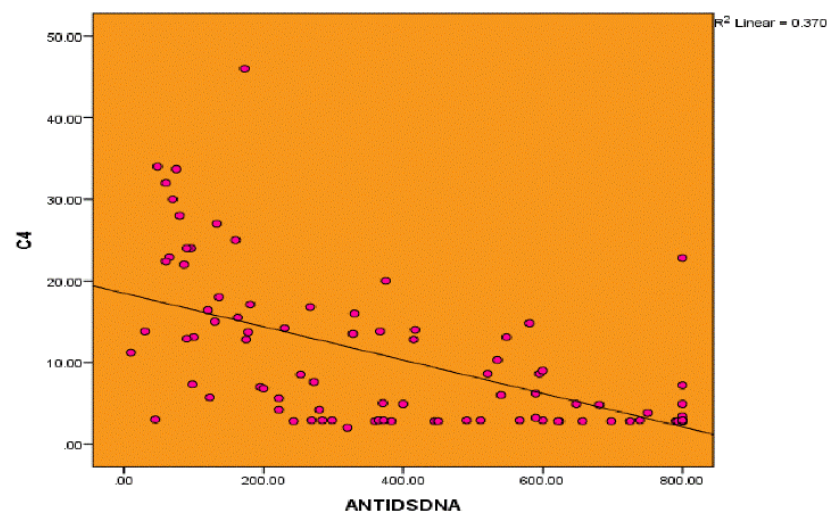

Pearson's correlation was run to determine the relationship between anti-dsDNA and C3, C4 and was found to be statistically significant (Table 4). 
Table 2. Comparison of C3 with SLEDAI.

\begin{tabular}{|l|l|l|l|l|l|l|}
\hline C3 & $\mathbf{n}$ & $\begin{array}{l}\text { Mean } \\
\text { SLEDA }\end{array}$ & $\begin{array}{l}\text { Std. } \\
\text { Deviation }\end{array}$ & $\begin{array}{l}\text { Std. } \\
\text { Error }\end{array}$ & \multicolumn{2}{l|}{$\begin{array}{l}\text { 95\% Confidence Interval for } \\
\text { Mean }\end{array}$} \\
\hline Normal & 21 & 10.9524 & 5.85215 & 1.27704 & 8.2885 & 13.6162 \\
\hline Low & 28 & 14.8214 & 6.00033 & 1.13396 & 12.4947 & 17.1481 \\
\hline Very Low & 51 & 21.4314 & 4.88776 & .68442 & 20.0567 & 22.8061 \\
\hline Total & 100 & 17.3800 & 6.91913 & .69191 & 16.0071 & 18.7529 \\
\hline
\end{tabular}

$\mathrm{F}=32.111 * *, \mathrm{p}<0.001$.

Table 3. Comparison of C4 with SLEDAI.

\begin{tabular}{|l|l|l|l|l|l|l|}
\hline C4 & $\mathbf{n}$ & $\begin{array}{l}\text { Mean } \\
\text { SLEDA }\end{array}$ & $\begin{array}{l}\text { Std. } \\
\text { Deviation }\end{array}$ & $\begin{array}{l}\text { Std. } \\
\text { Error }\end{array}$ & \multicolumn{2}{l|}{$\begin{array}{l}\text { 95\% Confidence Interval for } \\
\text { Mean }\end{array}$} \\
\cline { 5 - 7 } & & & & & Lower Bound & Upper Bound \\
\hline Normal & 15 & 8.4000 & 4.54816 & 1.17433 & 5.8813 & 10.9187 \\
\hline Low & 21 & 12.3810 & 4.17703 & .91150 & 10.4796 & 14.2823 \\
\hline Very Low & 64 & 21.1250 & 4.82882 & .60360 & 19.9188 & 22.3312 \\
\hline Total & 100 & 17.3800 & 6.91913 & .69191 & 16.0071 & 18.7529 \\
\hline
\end{tabular}

$\mathrm{F}=60.569^{* *}, \mathrm{p}<0.00$.

Table 4. Correlations analyses between c3 and C4.

\begin{tabular}{|l|l|l|}
\hline & C3 & C4 \\
\hline Pearson Correlation & $-.432^{* *}$ & $-.608^{* *}$ \\
\hline Sig. (2-tailed) & .000 & .000 \\
\hline N & 100 & 100 \\
\hline
\end{tabular}

**Correlation is significant at the 0.01 level (2-tailed).

\section{Discussion}

Systemic lupus erythematosus is a protean autoimmune disease where autoantibodies are frequently targeted against intracellular antigens of the cell nucleus double stranded and single stranded DNA, histones and extracellular nuclear antigens (ENA). Anti-ds DNA and anti-ssDNA were found in more than $60 \%$ of patients with active nephritis but in only $10 \%$ to $15 \%$ of those with inactive disease. Characteristically, exacerbations of nephritis in these patients were preceded by the appearance of anti-DNA antibodies and a drop-in serum complement (11).

Although it is important to study patients to ensure clinical relevance, strong evidence for a directly pathogenic role of anti-dsDNA antibodies came from work using animal models. There is a significant body of work that examines the effect that small changes in antigen-binding site have an antibody binding properties in vitro and in vivo. By studying panels of murine (12) and human (13) monoclonal anti-dsDNA antibodies, it has been shown that there is a high prevalence of arginine, asparagine and lysine residues in the complementarity determining regions of anti-dsDNA antibodies. It is proposed that the presence and position of these amino acids facilitate the antibody-DNA interaction (14). Within a single patient, these antibodies may be deposited by different mechanisms in different tissues or even within a single tissue. Both isotype and binding properties of anti-dsDNA antibodies affect association with disease activity. IgG anti-dsDNA antibodies are particularly important.

Anti-dsDNA antibodies are associated with systemic lupus and nephritis, but not subacute cutaneous lupus or discoid lupus. The best method for detecting anti-dsDNA remains controversial $(15,16)$. The most common techniques in the UK are dsDNA ELISA, Certhiidae luciliae IIF (CLIF) or Farr immunoprecipitation assay. All isotypes are detected by Farr assays, ELISA or CLIF, which use polyspecific serum.

In the present study, $65.9 \%$ of patients with active disease were anti-dsDNA positive. $26.2 \%$ of patients with inactive disease and $7.9 \%$ of healthy controls were anti-dsDNA 
positive. The anti-dsDNA positivity in active disease was in accordance with the earlier study (17). In contrast, antidsDNA positivity in inactive disease was little higher than the study by Schur and Sandson. This could be accounted for Serologically Active, Clinically Quiescent (SACQ) disease. There is a subgroup of patients with persistently high, anti-dsDNA despite having no disease activity. $\mathrm{Ng}$ et al. reported that high anti-nucleosome levels were associated with a higher number of disease flares and reduced time to first flare over the next 5 years (18). As per the earlier studies $1-5 \%$ of healthy people are positive for ANA, anti-dsDNA antibody and this coincides with anti-dsDNA in healthy controls in our study.

In our study $48 \%$ of patients with active disease presented with high titer anti-dsDNA antibody. As per the previous studies, there is a significant relationship between disease activity and the serum titer of anti-dsDNA (19). As mentioned earlier rises in anti-dsDNA antibody level were associated with flares of activity, either in the kidney or in other organs. In this study, serial measurement of antidsDNA titers was not done as the resources are limited compared to turnover of patients. But these patients while under study showed a very high titer of anti-dsDNA.

Concentrations of complement components $\mathrm{C} 3$ and $\mathrm{C} 4$ in serum are used as indicators of complement consumption in immune complex diseases. Because complement activation occurs during disease flares in SLE, one might expected complement proteins to be consumed and activation-derived products to be generated at a rate proportional to the degree of disease activity (20). Since Vaughen et al (21) first reported an association between decreased complement proteins and active SLE, numerous studies have been conducted to evaluate the worth of measuring serum complement levels in monitoring disease activity.

Although serum C3 and C4 serves as a marker of disease activity, a number of complement activation products from the classical pathway, alternative pathway and the common terminal pathway have been investigated as potential disease markers or predictors of disease SLE. A prospective study of patients with SLE studied monthly noted that a decrease in the serum levels of $\mathrm{C} 3$ and $\mathrm{C} 4$ was not consistently associated with global measures of disease activity (22). Despite its limitations, measurement of native $\mathrm{C} 3$ and $\mathrm{C} 4$ levels has not been replaced by that of cell bound or split products of complement in current clinical practice (23).

The quantitation of serum complement components is usually performed by radial immunodiffusion (RID). Other methods are nephelometry and turbidimetry, which are more accurate. Quantitative immunofluorescence (QIF) system is also used for quantitation of complement components $\mathrm{C} 3$ and $\mathrm{C} 4$.

The method adopted for serum C3 and C4 assay in our study was RID. Serum C3 was found to be very low in $51 \%$ and low in $28 \%$ of patients with active lupus. It was found to be normal in $21 \%$ of patients with active lupus. Serum C3 had a negative correlation with anti-dsDNA titers.

Lloyd and Schur reported that significantly decreased levels of CH50 and serum C3 and C4 were associated with increased SLE disease activity (24). However, decreased serum C4 levels were also low in a large portion of patients with stable SLE disease activity. Using either crosssectional or prospective studies, several investigators have subsequently shown that fluctuations in serum C3 levels correlated more significantly with the changes in activity/severity of SLE than serum C4 levels (25).

The serum $\mathrm{C} 4$ level in our study showed a very low, low and normal levels in $64 \%, 21 \%$ and $15 \%$ respectively in active disease. Negative correlation was detected between anti-dsDNA titers and C4 levels. Hence, in our study C3 and $\mathrm{C} 4$ levels were found to be low in patients with active disease. Some studies have suggested that serum C3 levels have no correlation with disease activity (26), while others observed that serum $\mathrm{C} 4$ appeared to decrease prior to clinical exacerbations 11. These observations reflect a more general disagreement regarding the role of $\mathrm{C} 3$ and $\mathrm{C} 4$, separately or together, as reliable markers of disease activity.

Our study support the notion that a low $\mathrm{C} 3$ and $\mathrm{C} 4$ serves as serological markers in the assessment of SLE disease activity.

Assay of these serological markers anti-dsDNA, C3 and C4 not only helps to detect disease activity, but also in modifying therapy so that a clinical flare can be avoided. The first trial to investigate this possibility was carried out by the Bootsma group in the mid-1990s (27).This study found the group in whom prednisolone dose was increased straightaway whenever anti-dsDNA level rose did have significantly fewer flares of the disease, but also 
experienced more adverse effects of steroids, and more than one quarter of this group discontinued the trial. Therapies directed at the B cells that make anti-dsDNA antibodies show promise for the treatment of SLE.

\section{Conclusion}

Therapeutic modification can be done based on the antidsDNA titers so as to reduce clinical flares, Quantitative anti-dsDNA ELISA test can be adopted as the standard testing method since it is cost effective, simple and sensitive. For monitoring disease activity in lupus, a combination of anti-dsDNA, C3 andC4 assays provides the most useful clinical information. As RID is a simple procedure, it can be substituted for nephelometry and turbidimetry in places where these costly equipments are not available. Oral administration of insulin during the first 2 weeks graded these changes, causing transcription activation of AIRE, Deaf1, Foxp3, Ctla4 and IL10 genes.

\section{Ethics Committee Approval: NA Informed Consent: NA}

Peer-review: Externally peer-reviewed.

Conflict of Interest: No conflict of interest was declared by the author.

Financial Disclosure: The author declared that this study has received no financial support.

\section{References}

1. Hohan C, Datta SK. Lupus key pathogenic mechanisms and contributing factors. Clin Immunol Immunopathol. 1996; 77:209-220.

2. Daniel Wallace, Bevra Hahn. Dubois Lupus Erythematosus and Related Syndromes 8th edition, Elsevier, Saunders, 2012; Chapter 43:p526.

3. Solomon DH, Kavanough AJ, Schur PH, and American College of Rheumatology Ad Hoc Committee on immunologic Testing Guidelines: Evidence-based guidelines for the use of immunologic tests: Antinuclear antibody testing: Arthritis Rheum 2002; 47:434-444.

4. Daniel Wallace, Bevra Hahn. Dubois Lupus Erythematosus and Related Syndromes 8th edition, Elsevier, Saunders, 2012; Chapter 20:p275.

5. Isenberg D. Smenk R. Clinical laboratory assays for measuring anti-dsDNA antibodies. Where are we now? Lupus. 2001;11:797-800.

6. Hermann M.VollR.KaldenVR.Etiopathogenesis of systemic lupus erythematosus. Immunol Today. 2000;21:424-426.

7. Sturfelt G.Truedsson complement and its breakdown products in SLE. Rheumatol. 2005;44:1227-1232.

8. Daniel Wallace, Bevra Hahn. Dubois Lupus Erythematosus and Related Syndromes 8th edition, Elsevier, Saunders, 2012; Chapter 43 P:527.
9. RadiceA. Sinico RA. A new oligonucleotide-based ELISA for the detection of anti-double stranded DNA antibodiesAutoimmunity 2006;39:113-119.

10. Bruns A. Blass S. Hausdorf G. Burmester GR. HiepeF. Bruns A. BlassS. Hausdorf G.Burmester GR. Hiepe F. Nucleosomes are major $\mathrm{T}$ and $\mathrm{B}$ cell autoantigens in systemic lupus erythematosus. Arthritis Rheum 2000;43:2307-2315.

11. Daniel Wallace, Bevra Hahn. Dubois Lupus Erythematosus and Related Syndromes 8th edition, Elsevier, Saunders, 2012; Chapter 43 P:427.

12. Bootsma H. Spronk P. Derksen R, et al. Prevention of relapses in systemic lupus erythematosus. Lancet. 1995; 345(8965):1595-1599.

13. Tseng CE, Buyon JP, Kim M. The effect of moderate dose cortico steroids in preventing severe lupus erythematosus findings of a prospective, randomized, double-blind, placebocontrolled trial. Arthritis Rheum. 2006;54(11)3623:36-32.

14. Daniel Wallace, Bevra Hahn. Dubois Lupus Erythematosus and Related Syndromes 8th edition, Elsevier Saunders, 2012; Chapter 43:275.

15. Eilat DT. The measurement of anti-DNA creativity in the sera of patients with SLE Theoretical and practical considerations. Autoimmunity. 1989;3:299-6.

16. Isenberg DA, Dueney-C, Williams E, et al. Measurement of anti-DNA antibodies; a reappraisal using five different methods. Ann Rheum Dis. 1987;46:448-56.

17. Daniel Wallace, Bevra Hahn. Dubois Lupus Erythematosus and Related Syndromes 8th edition, Elsevier, Saunders, 2012; Chapter 20:p325.

18. Ng KP, Manson JJ, Rahman A. Isenberg DA. Association of antinucleosome antibodies with disease flare in serologically active clinically quiescent patients with systemic lupus erythematosus. Arthritis Care Res. 2006;55:900-904.

19. Daniel Wallace, Bevra Hahn. Dubois Lupus Erythematosus and Related Syndromes 8th edition, Elsevier, Saunders, 2012; Chapter 43:p526

20. Schur PH, Sandson J. Immunological factors and clinical activity in systemic lupus erythematosus. N Engl J Med. 1968; 278:533-538.

21. Vaughan JH, Bayles TB, Favour CB. The response of serum gamma globulin level and complement titer to adrenocorticotrophic harmone (ACTH) therapy in lupus erythematosus disseminates. J Lab Clin Med. 1951;37:698-702. 22. Ho A, Barr SG, Magder LS. A decrease in complement is associated with increased renal and hematological activity in patients with systemic erythematosus. Arthritis Rheum. 2001; 44:2350-2357.

23. Lloyd W, Schur PH. Immune complexes, complement and anti-DNA in exacerbations of systemic lupus erythematosus (SLE), Medicine. 1981;60:208-217.

24. Valentijn RM, van Overhagen H, Hazevoet HM, Hermans J, Cats $\mathrm{A}$, et al. The value of complement and immune complex determinations in monitoring disease activity in patients with systemic lupus erythematosus. Arthritis Rheum. 1985;28:904913.

25. Cameron JS, Lessof MH, Ogg CS, Williams BD, Williams DG. Disease activity in the Nephritis of systemic lupus erythematosus in relation to serum complement concentrations, DNA-binding capacity, and precipitating anti-DNA antibody. 
Clin Exp Immunol. 1976;25(3):418-427.

26. Swaak J, Groenwold J, Broaxveld W. Predictive value of complement profiles and anti-dsDNA in systemic erythematosus. Ann Rhuem Dis. 1986;45:359-366.

27. Reichlin M. ANA negative systemic lupus erythematosus sera revised serologically. Lupus. 2000;9(2):116-119.

Submit your next manuscript to the JICM and take full advantage of:

- Convenient online submission,

- Thorough peer review, Fast Response,

- No charges,

- Immediate publication on acceptance,

- Inclusion in Scopemed and High quality indexes,

- Research which is freely available for redistribution of the worldwide literature

To submit your manuscript, click on $h t t p: / / w w w . j i a c m . c o m$

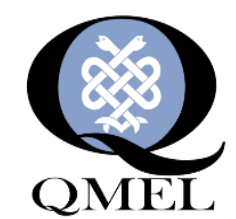

Medicine \& Publishing

Published by The ${ }^{\circledR}$ QMEL.org

Medicine \& Education \& Library

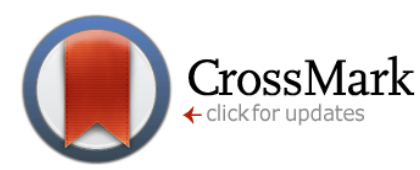

